\title{
The Kinetics of Pb Removal from Brass Scrap Using Compound Separation
}

\author{
Hidekazu Sueyoshi' ${ }^{*}$, Masashi Miyazaki², Takuya Okada², Nobuyuki Ashie², Yoshiharu Kousaka² \\ ${ }^{1}$ Graduate School of Science and Engineering, Kagoshima University, Kagoshima, Japan \\ ${ }^{2}$ San-Etsu Metals Co. Ltd., Tonami, Japan \\ Email: k9415634@kadai.jp, kousaka@p2332.nsk.ne.jp
}

How to cite this paper: Sueyoshi, H., Miyazaki, M., Okada, T., Ashie, N. and Kousaka, Y. (2018) The Kinetics of Pb Removal from Brass Scrap Using Compound Separation. International Journal of Nonferrous Metallurgy, 7, 39-55. https://doi.org/10.4236/ijnm.2018.74004

Received: October 13, 2018

Accepted: October 28, 2018

Published: October 31, 2018

Copyright ( 92018 by authors and Scientific Research Publishing Inc. This work is licensed under the Creative Commons Attribution International License (CC BY 4.0).

http://creativecommons.org/licenses/by/4.0/

(c) (i) Open Access

\begin{abstract}
$2 \mathrm{wt} \% \mathrm{Ca}$ was added to molten brass containing $3.2 \mathrm{wt} \% \mathrm{~Pb}$. The composition and grain size of the formed $\mathrm{Ca}-\mathrm{Pb}$ compound were examined in detail using SEM-EDS and XRD. This revealed that the composition of the $\mathrm{Ca}-\mathrm{Pb}$ compound depends on the grain size of the liquid phase $\mathrm{Pb}$ and the diffusion phenomenon of the $\mathrm{Ca}$ in the $\mathrm{Ca}-\mathrm{Pb}$ compound formed on the surface of the $\mathrm{Pb}$. When the $\mathrm{Pb}$ has a fine grain, a compound composed only of $\mathrm{Ca}-\mathrm{Pb}$ compounds is formed. When the grain size of the $\mathrm{Pb}$ is several $\mu \mathrm{m}, \mathrm{Ca}-\mathrm{Pb}$ compounds containing unreacted $\mathrm{Pb}$ in the center are formed. These compounds aggregate into a larger compound grain. From the evaluation of the floating force (the resultant force of the weight and buoyancy of the $\mathrm{Ca}-\mathrm{Pb}$ compounds formed) and the rising terminal velocity of the $\mathrm{Ca}-\mathrm{Pb}$ compound within the molten brass, it was found that the floating force and rising terminal velocity depend on the composition and grain size of the $\mathrm{Ca}-\mathrm{Pb}$ compound. It was found that since $\mathrm{Ca}-\mathrm{Pb}$ compounds with a floating force greater than $10^{-6} \mathrm{~g} \cdot \mathrm{cm} / \mathrm{s}^{2}$ have a very large rising terminal velocity, they reach the surface of the molten brass in a short time after compound formation and then continue to float on the surface of the molten brass. Thus they can be removed by skimming. The effects of the grain size of the $\mathrm{Ca}-\mathrm{Pb}$ compound on the floating force and the rising terminal velocity were greater than those of the composition of the $\mathrm{Ca}-\mathrm{Pb}$ compound.
\end{abstract}

\section{Keywords}

Lead Removal, Brass Scrap, Compound Separation, Kinetics

\section{Introduction}

Brass alloys are characterized by high thermal and electric conductivity as well as high antibacterial properties. Brass alloys containing $\mathrm{Pb}$ have better machinabil*Professor Emeritus. 
ity than other metallic materials because the added $\mathrm{Pb}$ significantly reduces the tool wear and cutting force required to work it while producing excellent chip breakage action. However, $\mathrm{Pb}$ has been recognized as being harmful to human health. In Japan, the permitted level of $\mathrm{Pb}$ that can be leached into drinking water supplies was revised to $0.01 \mathrm{mg} / \mathrm{L}$ in April 2003 [1]. In the European-based $\mathrm{REACH}$ program, the limit of the $\mathrm{Pb}$ contained in brass alloys has been decreased $0.5 \mathrm{wt} \%$ from June 2016 [2]. In the USA, the $\mathrm{Pb}$ content in water-bearing materials has been limited to $0.25 \mathrm{wt} \%$ since 2014 [3].

Brass alloys have generally been manufactured by recycling brass alloy scrap. An important issue regarding sustainability is how to use as much recycled brass as possible. The simplest method to reduce the $\mathrm{Pb}$ in a brass alloy is to dilute the molten brass by adding virgin $\mathrm{Pb}$-free materials. However, the accumulation of large amounts of unrecycled scrap is presenting a problem for sustainability. For this reason, dilution method confuses the recycling system functioning at present. There are several $\mathrm{Pb}$ removal methods, such as electrolytic decomposing [4] and pyrometallurgical decomposing [5]. However, a large scale additional infrastructure is needed at most brass mills when they try to introduce these methods. A method for Pb removal by compound separation using Ca-Si compound and $\mathrm{NaF}$ addition was first reported by the authors et al. [6] [7]. This method has the great practical advantage that additional infrastructure is unnecessary. In addition, the authors et al. also reported on the lifecycle assessment (LCA) of manufacturing Pb-free copper alloys [8]. It was found from LCA analysis that the conversion of the conventional system that uses virgin materials to a new system that uses recycled $\mathrm{Pb}$-free copper alloy decreases environmental impacts. The mechanism of $\mathrm{Pb}$ removal from brass scrap by compound separation using $\mathrm{Ca}$ and $\mathrm{NaF}$ was later reported by the authors et al. [9]. On the other hand, Hilgendorf et al. reported performing $\mathrm{Pb}$ removal by a fluorine-free method adding $\mathrm{Ca}$ alone [5]. According to their results, the actual $\mathrm{Pb}$ removal rate obtained using an experimental furnace was about $20 \%$, although the theoretical $\mathrm{Pb}$ removal rate calculated for a $\mathrm{Cu}-\mathrm{Zn}-\mathrm{Pb}-\mathrm{Ca}-\mathrm{O}$ system using thermochemical simulation software was $96 \%$. This suggests that further elucidation of the mechanism for the formation and removal of $\mathrm{Ca}-\mathrm{Pb}$ compound is needed to achieve a high $\mathrm{Pb}$ removal rate using a fluorine-free method. However, there are not many reports about $\mathrm{Pb}$ removal using compound separation. There are also many unclear points outstanding.

According to the results reported to date [5] [6] [7] [9], the $\mathrm{Pb}$ removal rate is about $20 \%$ in the case of the addition of a Ca-Si compound or $\mathrm{Ca}$ alone and it increases to $83 \%$ with the subsequent addition of $\mathrm{NaF}$. It is considered that the $\mathrm{Pb}$ removal rate depends on the characteristics of the produced $\mathrm{Ca}-\mathrm{Pb}$ compound and its resulting buoyancy. However, the mechanisms of the formation of $\mathrm{Ca}-\mathrm{Pb}$ compounds and the kinetics of $\mathrm{Ca}-\mathrm{Pb}$ compounds in molten brass have not yet been fully elucidated. Clarification of the effects of the composition and the grain size of $\mathrm{Ca}-\mathrm{Pb}$ compounds on its buoyancy would enable further development of methods for $\mathrm{Pb}$ removal by compound separation. Mechanisms for 
the formation of $\mathrm{Ca}-\mathrm{Pb}$ compounds and the kinetics of the $\mathrm{Ca}-\mathrm{Pb}$ compound in the molten brass were therefore investigated in the present study.

\section{Experimental}

Brass scrap (chemical composition: $59.6 \mathrm{wt} \% \mathrm{Cu}, 3.2 \mathrm{wt} \% \mathrm{~Pb}, 0.3 \mathrm{wt} \% \mathrm{Sn}, 0.16$ wt\% Fe, $0.05 \mathrm{wt} \% \mathrm{Ni}$, and bal. Zn, ingot weight: $30 \mathrm{~kg}$ ) was melted using a graphite crucible $(235 \mathrm{~mm}$ inner diameter, $150 \mathrm{~mm}$ bottom diameter and $310 \mathrm{~mm}$ height (Nippon Crucible, Tokyo, Japan)) in a $6-9 \mathrm{kHz}$ induction furnace (MELT-COMP-80K, Tamagawa Engineering, Fukushima, Japan) in the atmosphere. The temperature was measured using an inset type of optical fibre pyrometer (FIMTHERM-HM, Seiyo Industry, Yokohama, Japan). A Ca-cored brass wire containing $2 \mathrm{wt} \% \mathrm{Ca}(13.6 \mathrm{~mm}$ outer diameter and $12.8 \mathrm{~mm}$ inner diameter (WING ON, Tokyo, Japan)) was injected to the molten brass at $930^{\circ} \mathrm{C}$. Then stirring was carried out for $1 \mathrm{~min}$, followed by holding (without stirring) for 5 $\mathrm{min}$. Small sample disks, $40 \mathrm{~mm}$ in diameter and $25 \mathrm{~mm}$ in thickness, were produced for chemical composition analysis after three different stages post melting: after the addition of $\mathrm{Ca}$ and subsequent stirring for $1 \mathrm{~min}$, and after holding (without stirring) for $5 \mathrm{~min}$. The small sample disks were produced by partial casting using a ladle and metal molds. The microstructure of the small sample disks was examined using scanning electron microscopy-energy dispersive X-ray spectroscopy (SEM-EDS) (SEM; JSM-7001F, JEOL, Tokyo, Japan, EDS; INCAx-act, Oxford Instruments, Oxfordshire, United Kingdom) and X-ray diffraction (XRD) (Smart Lab $9 \mathrm{~kW}$, Rigaku, Tokyo, Japan) with $\mathrm{Cu}-\mathrm{K} \alpha$ radiation. The electric voltage and current applied to the X-ray tube used for XRD were $45 \mathrm{kV}$ and $200 \mathrm{~mA}$, respectively. The scanning rate and step angle were $50^{\circ} / \mathrm{min}$ and $0.02^{\circ}$, respectively. The chemical composition of the small sample disk was examined using X-ray fluorescence (XRF) (Simultix 14, Rigaku, Tokyo, Japan).

\section{Results and Discussion}

\subsection{Characteristic of Ca-Pb Compounds}

Figure 1 shows the SEM-EDS results for a small sample disk produced by partial casting after melting brass scrap. It was found from EDS area analysis that the white region in the BSE image is $\mathrm{Pb}$. Pb grains were smaller than $3 \mu \mathrm{m}$ and sub- $\mu \mathrm{m}$ grains were also present.

Figure 2 shows the XRD profile of a small sample disk produced by partial casting after melting brass scrap. $\alpha$-phase brass [10], $\beta$-phase brass [11] and $\mathrm{Pb}$ [12] were identified. The intensity ratio of each plane peak for the $\alpha$-phase and $\beta$-phase brass was somewhat different from that obtained using the powder method. This is because the cast structure consists of preferred-oriented crystal grains.

Figure 3 shows the SEM-EDS results for a small sample disk produced immediately after the addition of $\mathrm{Ca}$ and subsequent stirring. $\mathrm{Cu}, \mathrm{Zn}, \mathrm{Ca}, \mathrm{Pb}, \mathrm{Sn}$ and $\mathrm{O}$ were detected in the white region in the SE image. There was no region where 


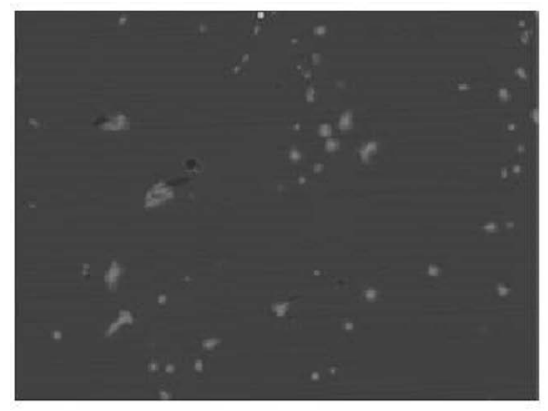

$10 \mu \mathrm{m} \quad \mathrm{BSE}$

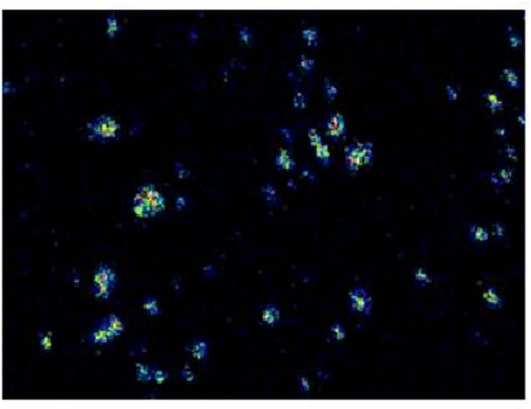

$\mathbf{P b}$

Figure 1. SEM-EDS results for a small sample disk produced by partial casting after melting brass scrap.

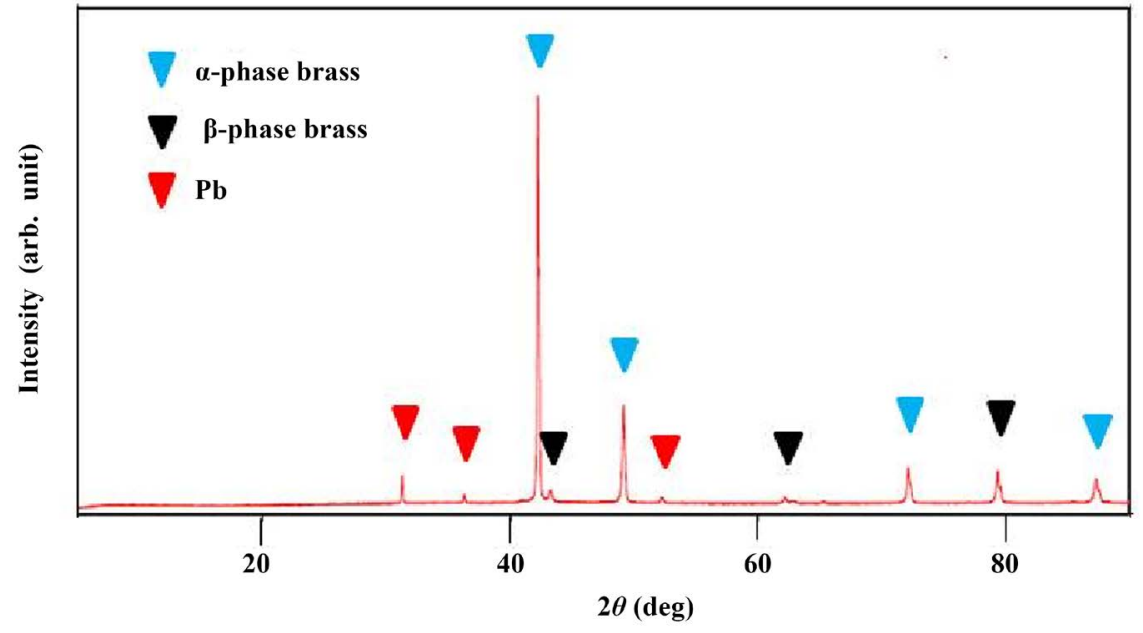

Figure 2. XRD profile of a small sample disk produced by partial casting after melting brass scrap.

only $\mathrm{Pb}$ was detected. $\mathrm{Ca}$ was always detected in the region where $\mathrm{Pb}$ was detected. This suggests that a $\mathrm{Ca}-\mathrm{Pb}$ compound was formed and $\mathrm{Cu}, \mathrm{Zn}, \mathrm{Sn}$ and $\mathrm{O}$ were present in it. Fine $\mathrm{Ca}-\mathrm{Pb}$ compound having a grain size of $1 \mu \mathrm{m}$ or less was not observed. The grain size of most of the $\mathrm{Ca}-\mathrm{Pb}$ compounds was in the range of several $\mu \mathrm{m}$ to $30 \mu \mathrm{m}$. This suggests that aggregation of $\mathrm{Ca}-\mathrm{Pb}$ compounds occurred. It is thought that $\mathrm{Ca}-\mathrm{Pb}$ compounds larger than $30 \mu \mathrm{m}$ floated on the surface of the molten brass. On the other hand, the concentration of $\mathrm{Ca}$ in the small sample disk measured using XRF was $1.59 \mathrm{wt} \%$. The concentration of $\mathrm{Ca}$ is due to the presence of both $\mathrm{Ca}-\mathrm{Pb}$ compound and excess $\mathrm{Ca}$. It was found from Figure 3 that excess $\mathrm{Ca}$ was dissolved in the $\beta$-phase brass (the region where $\mathrm{Ca}$, $\mathrm{Cu}$ and $\mathrm{Zn}$ are detected but no $\mathrm{Pb}$ is detected) during solidification. The 0.41 $\mathrm{wt} \% \mathrm{Ca}$ consumed is due to a small amount of $\mathrm{CaO}$ [9] that was produced and $\mathrm{Ca}-\mathrm{Pb}$ compound that floated on the surface of the molten brass.

Figure 4 shows the SEM-EDS results for a small sample disk produced after holding (without stirring) for $5 \mathrm{~min}$. As shown in the $\mathrm{SE}$ image, the huge $\mathrm{Ca}-\mathrm{Pb}$ compound observed in Figure 3 disappeared and the grain size of most of the 

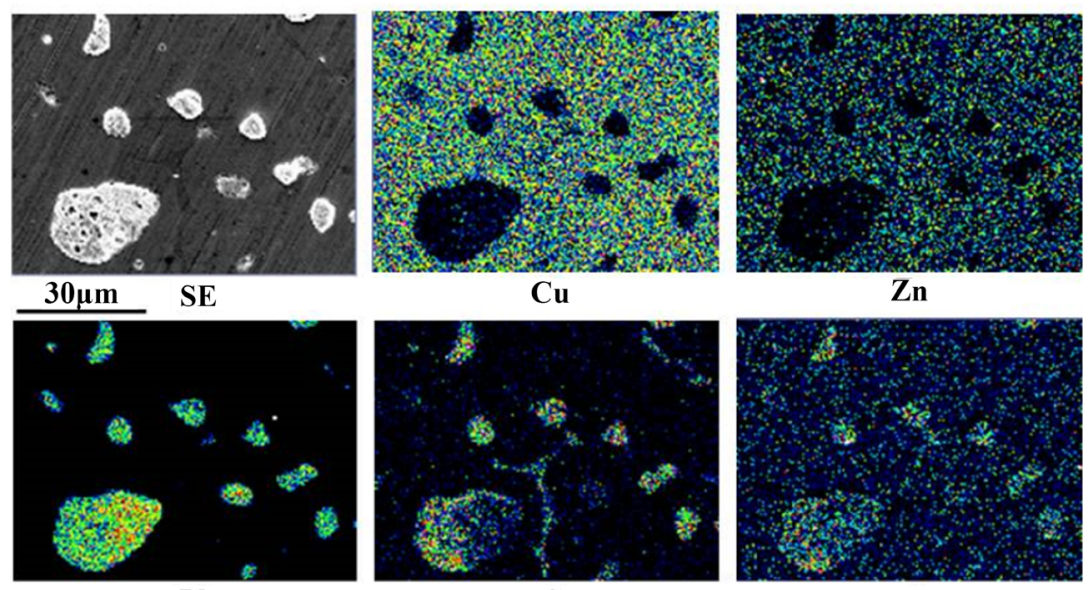

$\mathrm{Pb}$

Ca
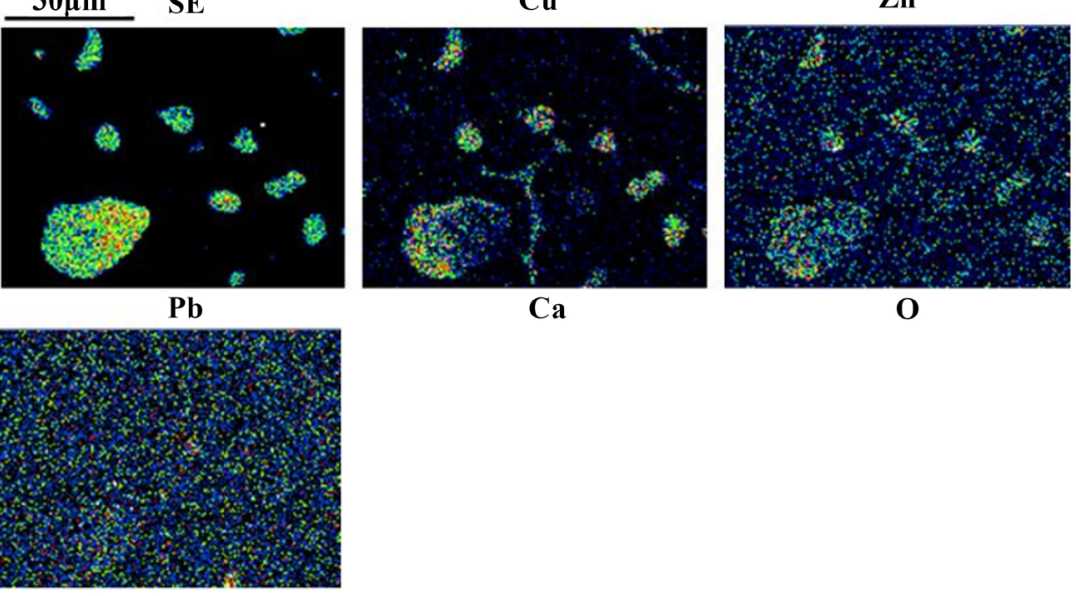

O

Sn

Figure 3. SEM-EDS results for a small sample disk produced immediately after Ca addition and subsequent stirring.
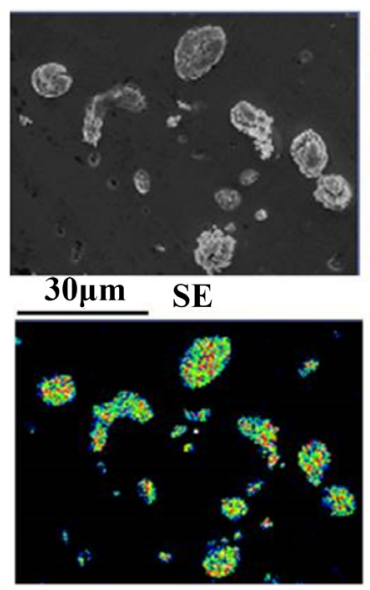

Pb

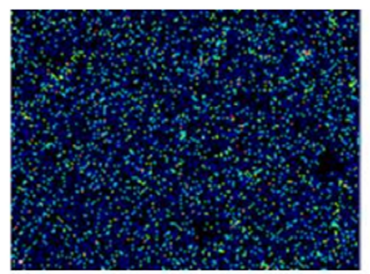

Sn

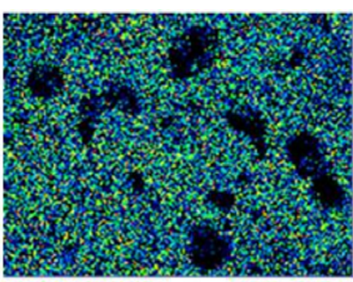

$\mathrm{Cu}$

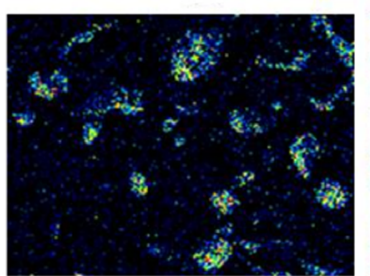

Ca

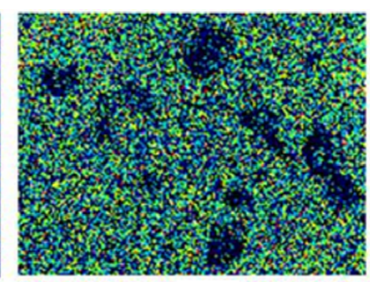

Zn

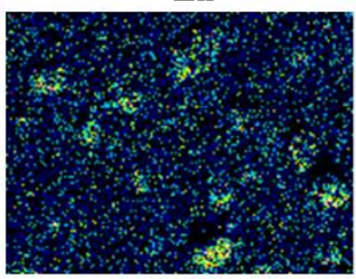

o

Figure 4. SEM-EDS results for a small sample disk produced after holding (without stirring) for $5 \mathrm{~min}$.

$\mathrm{Ca}-\mathrm{Pb}$ compounds was in the range of several $\mu \mathrm{m}$ to $10 \mu \mathrm{m}$. The results of area analysis were similar to those shown in Figure 3. 
Figure 5 shows the XRD profile of a small sample disk produced after holding (without stirring) for 5 min. $\alpha$-phase brass, $\beta$-phase brass, $\mathrm{Pb}, \mathrm{Ca}_{5} \mathrm{~Pb}_{3}$ [13], $\mathrm{CaZn}_{2}$ [14], $\mathrm{CaNi}_{2}$ [15] and $\mathrm{CaNi}_{3}$ [15] were identified. The intensity ratio of each plane peak for the $\alpha$-phase and $\beta$-phase brass was somewhat different from that obtained using the powder method. This is because the cast structure consists of preferred-oriented crystal grains. The intensity ratio ( $\mathrm{Pb} / \alpha$-phase brass) of the highest peak for $\mathrm{Pb}$ and $\alpha$-phase brass was lower than that shown in Figure 2. This suggests that the $\mathrm{Pb}$ content is lower than that of post melting. Liquid phase $\mathrm{Pb}$ did not aggregate in the molten brass as shown in Figure 1. It is believed that likewise liquid phase $\mathrm{Ca}-\mathrm{Pb}$ compound does not aggregate. Aggregation of the $\mathrm{Ca}-\mathrm{Pb}$ compound was observed as shown in Figure 3. This suggests that solid phase $\mathrm{Ca}-\mathrm{Pb}$ compounds were produced in the molten metal. According to the $\mathrm{Ca}-\mathrm{Pb}$ equilibrium phase diagram [16], $\mathrm{Ca}_{2} \mathrm{~Pb}, \mathrm{Ca}_{5} \mathrm{~Pb}_{3}$ and $\mathrm{CaPb}$ can exist as a solid phase at $930^{\circ} \mathrm{C}$. However $\mathrm{Ca}_{2} \mathrm{~Pb}$ [17] and $\mathrm{CaPb}$ [17] could not be clearly identified as shown in Figure 5. Hilgendorf et al. reported that according to a thermochemical simulation for a $\mathrm{Cu}-\mathrm{Zn}-\mathrm{Pb}-\mathrm{Ca}-\mathrm{O}$ system, $\mathrm{CaPb}$ was chiefly formed by the addition of $0.7 \mathrm{wt} \% \mathrm{Ca}, \mathrm{Ca}_{5} \mathrm{~Pb}_{3}$ was formed by adding $1.5 \mathrm{wt} \% \mathrm{Ca}$ and $\mathrm{Ca}_{2} \mathrm{~Pb}$ by $1.8 \mathrm{wt} \% \mathrm{Ca}$ and furthermore from SEM-EDS analysis, the $\mathrm{Ca} / \mathrm{Pb}$ ratio of the $\mathrm{Ca}-\mathrm{Pb}$ compound formed by $1.5 \mathrm{wt} \% \mathrm{Ca}$ addition was close to the stoichiometric $\mathrm{Ca} / \mathrm{Pb}$ ratio (1.67) of $\mathrm{Ca}_{5} \mathrm{~Pb}_{3}$ [5]. The authors et al. reported that XRD analysis of the slag skimmed from the surface of the molten brass after the addition of $2 \mathrm{wt} \% \mathrm{Ca}$ revealed that $\mathrm{Ca}_{2} \mathrm{~Pb}$ was formed in the molten brass, then $\mathrm{Ca}_{2} \mathrm{~Pb}$ was oxidized during air cooling after skimming off, resulting in the formation of $\mathrm{Ca}_{2} \mathrm{PbO}_{4}$ [9]. Therefore the result that $\mathrm{Ca}_{2} \mathrm{~Pb}$ and $\mathrm{CaPb}$ could not be clearly identified, as shown in Figure 5, does not mean that these $\mathrm{Ca}-\mathrm{Pb}$ compounds were not formed. It is thought likely to be due to a small amount of these $\mathrm{Ca}-\mathrm{Pb}$ compounds, that is, an amount less than XRD detection sensitivity. As shown in Figure 3 and Figure 4, a region of only $\mathrm{Pb}$ was

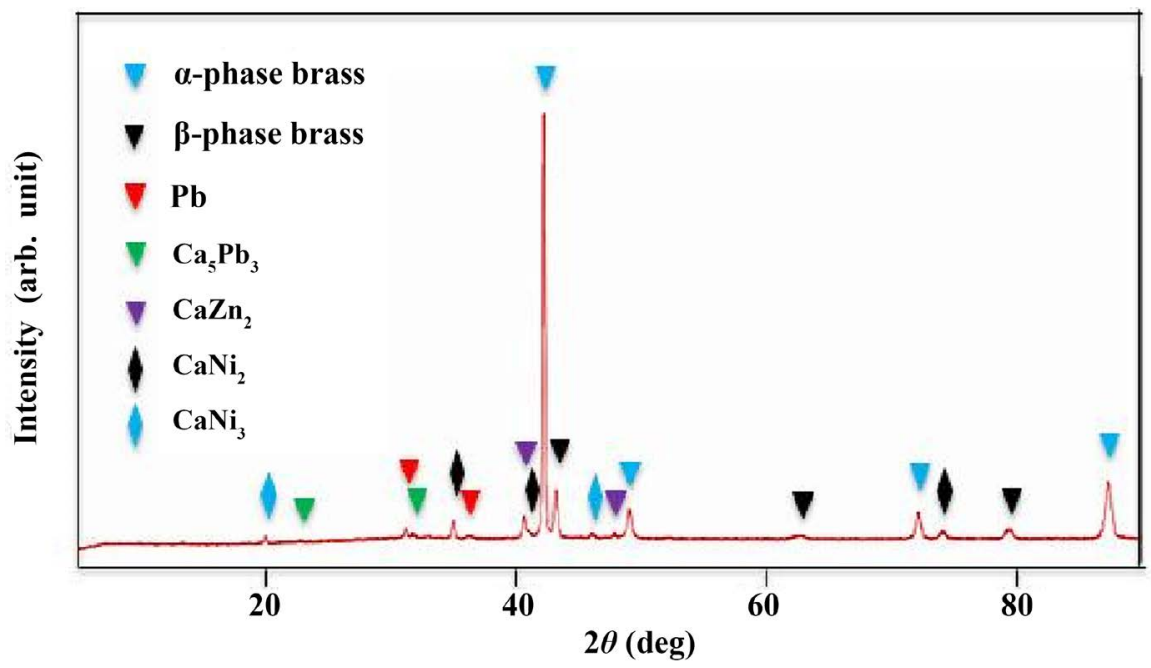

Figure 5. XRD profile of a small sample disk produced after holding (without stirring) for $5 \mathrm{~min}$. 
not found and $\mathrm{Ca}$ was always detected in a region where $\mathrm{Pb}$ was detected. In Figure 5, the peaks of $\mathrm{Ca}-\mathrm{Pb}$ compound and $\mathrm{Pb}$ were detected. These results suggest that unreacted $\mathrm{Pb}$ is present in the $\mathrm{Ca}-\mathrm{Pb}$ compound. According to the thermochemical simulation of the $\mathrm{Cu}-\mathrm{Zn}-\mathrm{Pb}-\mathrm{Ca}-\mathrm{O}$ system by Hilgendorf et al., the $\mathrm{Ca}-\mathrm{Zn}$ intermetallic phase is stable at $810^{\circ} \mathrm{C}$ or lower when excess $\mathrm{Ca}$ is present [5]. In the present study, $\mathrm{CaZn}_{2}, \mathrm{CaNi}_{2}$ and $\mathrm{CaNi}_{3}$ were identified as shown in Figure 5. However, the intensity ratio of each plane peak for the compounds was somewhat different from that obtained using the powder method. These compounds are considered to have formed during casting.

EDS quantitative analyses were carried out at 8 sites in a large $\mathrm{Ca}-\mathrm{Pb}$ compound (Figure 3 ) having a grain size of about $30 \mu \mathrm{m}$ and on the center of 15 $\mathrm{Ca}-\mathrm{Pb}$ compounds with a grain size of about $10 \mu \mathrm{m}$. Figure 6 shows the relationship between the $\mathrm{Cu}$ and $\mathrm{Zn}$ concentrations. Regardless of the grain size of the $\mathrm{Ca}-\mathrm{Pb}$ compound, a linear relation was established between the $\mathrm{Cu}$ and $\mathrm{Zn}$ concentrations. The ratio of $\mathrm{Zn}$ concentration to $\mathrm{Cu}$ concentration (that is, the slope of the straight line) was 0.51 , which almost agreed with the value (0.59) of the $\mathrm{Zn} / \mathrm{Cu}$ ratio obtained using XRF. This suggests that molten brass occupies the space between aggregating $\mathrm{Ca}-\mathrm{Pb}$ compound grains. As shown in Figure 6, the amount of molten brass in the $\mathrm{Ca}-\mathrm{Pb}$ compound with a grain size of $30 \mu \mathrm{m}$ was smaller than that in the $\mathrm{Ca}-\mathrm{Pb}$ compound with a grain size of $10 \mu \mathrm{m}$. From this, it is considered that the aggregated $\mathrm{Ca}-\mathrm{Pb}$ compound with a grain size of 30 $\mu \mathrm{m}$ was formed by aggregation of many $\mathrm{Ca}-\mathrm{Pb}$ compound particles smaller than the $\mathrm{Ca}-\mathrm{Pb}$ compound particles constituting the aggregated $\mathrm{Ca}-\mathrm{Pb}$ compound with a grain size of $10 \mu \mathrm{m}$.

Figure 7 shows the relationship between the $\mathrm{Pb}$ and $\mathrm{Ca}$ concentrations. The straight lines show the stoichiometric relationships between $\mathrm{Pb}$ and $\mathrm{Ca}$ concentrations in $\mathrm{Ca}_{2} \mathrm{~Pb}, \mathrm{Ca}_{5} \mathrm{~Pb}_{3}$ and $\mathrm{CaPb}$. The measured values were located under the

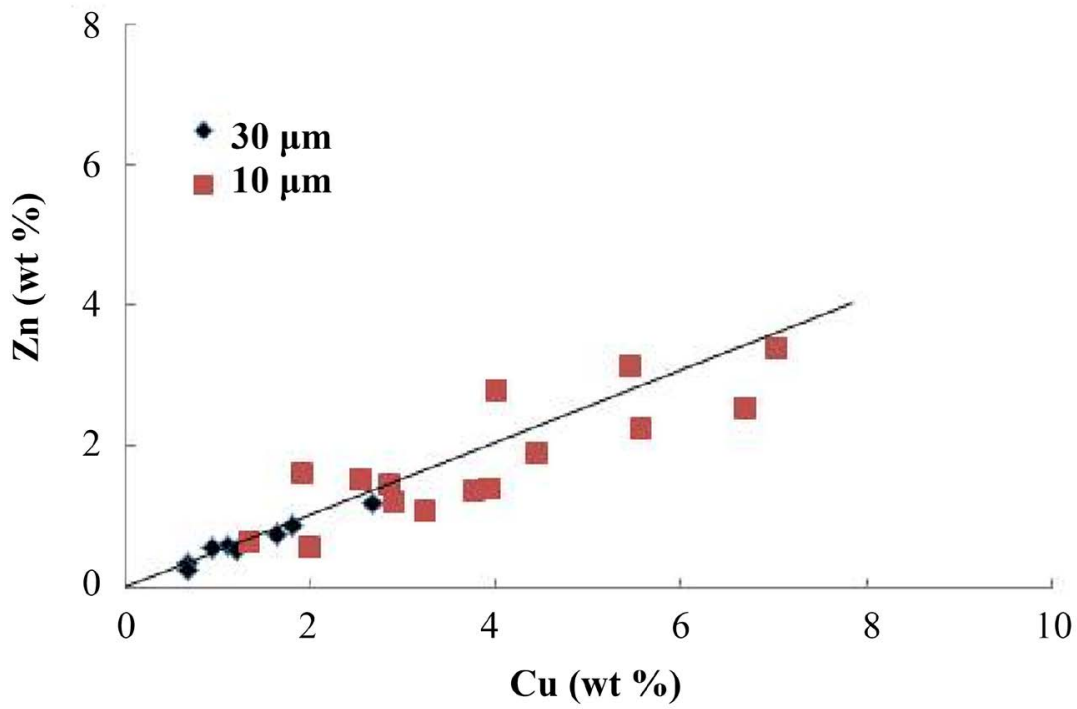

Figure 6. The relationship between the $\mathrm{Cu}$ and $\mathrm{Zn}$ concentrations for the $\mathrm{Ca}-\mathrm{Pb}$ compounds. 


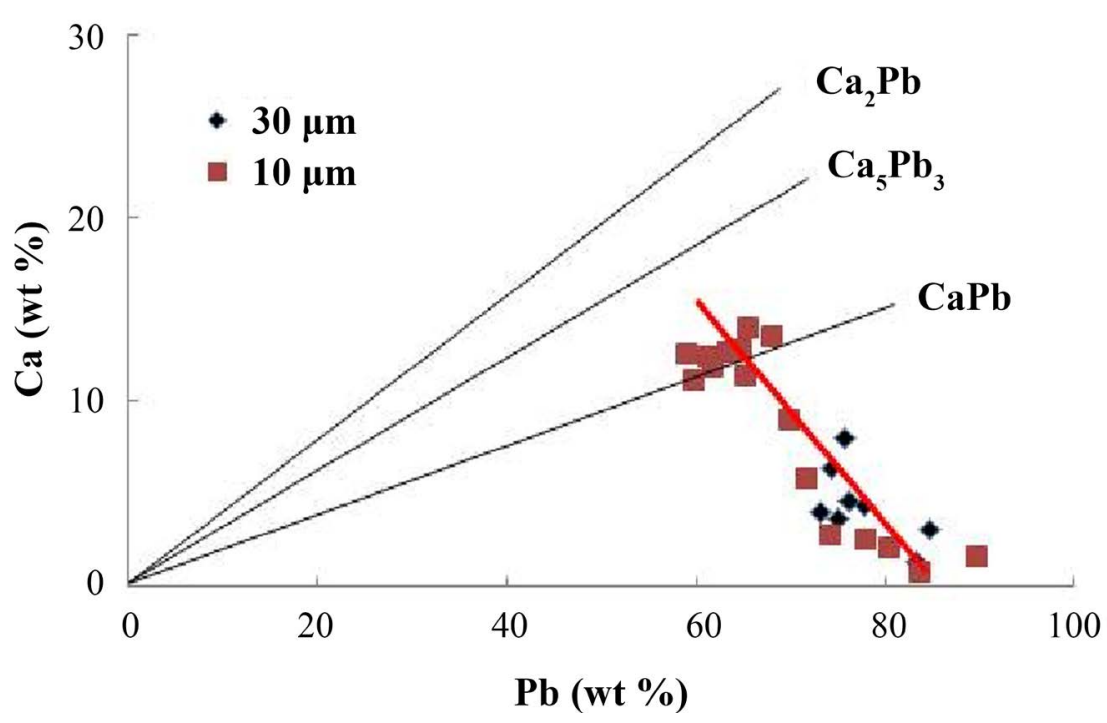

Figure 7. The relationship between the $\mathrm{Pb}$ and $\mathrm{Ca}$ concentrations for the $\mathrm{Ca}-\mathrm{Pb}$ compounds.

straight lines of $\mathrm{Ca}_{2} \mathrm{~Pb}$ and $\mathrm{Ca}_{5} \mathrm{~Pb}_{3}$. This result does not mean that $\mathrm{Ca}_{2} \mathrm{~Pb}$ and $\mathrm{Ca}_{5} \mathrm{~Pb}_{3}$ were not produced. Rather, is because unreacted $\mathrm{Pb}$ was present in the $\mathrm{Ca}-\mathrm{Pb}$ compound, as mentioned above. As indicated by the red line in Figure 7 , $\mathrm{Ca}$ concentration tended to decrease with increasing $\mathrm{Pb}$ concentration. This is considered to be due to the fact that unreacted $\mathrm{Pb}$ remains in the center of the $\mathrm{Ca}-\mathrm{Pb}$ compound, and the amount of unreacted $\mathrm{Pb}$ increases relatively as the amount of the $\mathrm{Ca}-\mathrm{Pb}$ compound formed on the surface is small.

Figure 8 shows the relationship between the $\mathrm{Cu}$ and $\mathrm{Sn}$ concentrations. There was no clear relationship between these. Sn concentration shown in Figure 8 was an order of magnitude larger than that obtained using XRF. This suggests that most of measured $\mathrm{Sn}$ is not due to brass alloy which occupies the space between aggregated $\mathrm{Ca}-\mathrm{Pb}$ compound grains.

Figure 9 shows the relationship between the $\mathrm{Ca}$ and $\mathrm{Sn}$ concentrations. A linear relation was found between the $\mathrm{Ca}$ and $\mathrm{Sn}$ concentrations. The ratio of $\mathrm{Ca}$ to $\mathrm{Sn}$, that is, the slope of the straight line, was 7.5. According to the Ca-Sn equilibrium phase diagram [18], $\mathrm{Ca}_{2} \mathrm{Sn}$ and $\mathrm{CaSn}$ can exist as a solid phase at $930^{\circ} \mathrm{C}$. The stoichiometric ratios $(\mathrm{Ca} / \mathrm{Sn})$ of $\mathrm{Ca}_{2} \mathrm{Sn}$ and $\mathrm{CaSn}$ were 0.67 and 0.34 , respectively. The slope of the straight line shown in Figure 9 was one order of magnitude larger than these values. However, no Ca-Sn compound peak was detected, as shown in Figure 5. On the other hand, a solid solution (0.42 wt\%) of Sn in only $\beta$-phase brass was revealed by EDS quantitative analysis. These results suggest that no reaction between $\mathrm{Ca}$ and $\mathrm{Sn}$ occurs but some of the $\mathrm{Sn}$ is dissolved in the $\mathrm{Ca}-\mathrm{Pb}$ compound and that the remaining $\mathrm{Sn}$ forms a solid solution in the $\beta$-phase brass during the solidification process. As shown in Figure 9, the Sn concentration increased roughly proportionally with the increasing $\mathrm{Ca}$ concentration or the amount of the $\mathrm{Ca}-\mathrm{Pb}$ compound. This suggests that there is a solubility limit. 


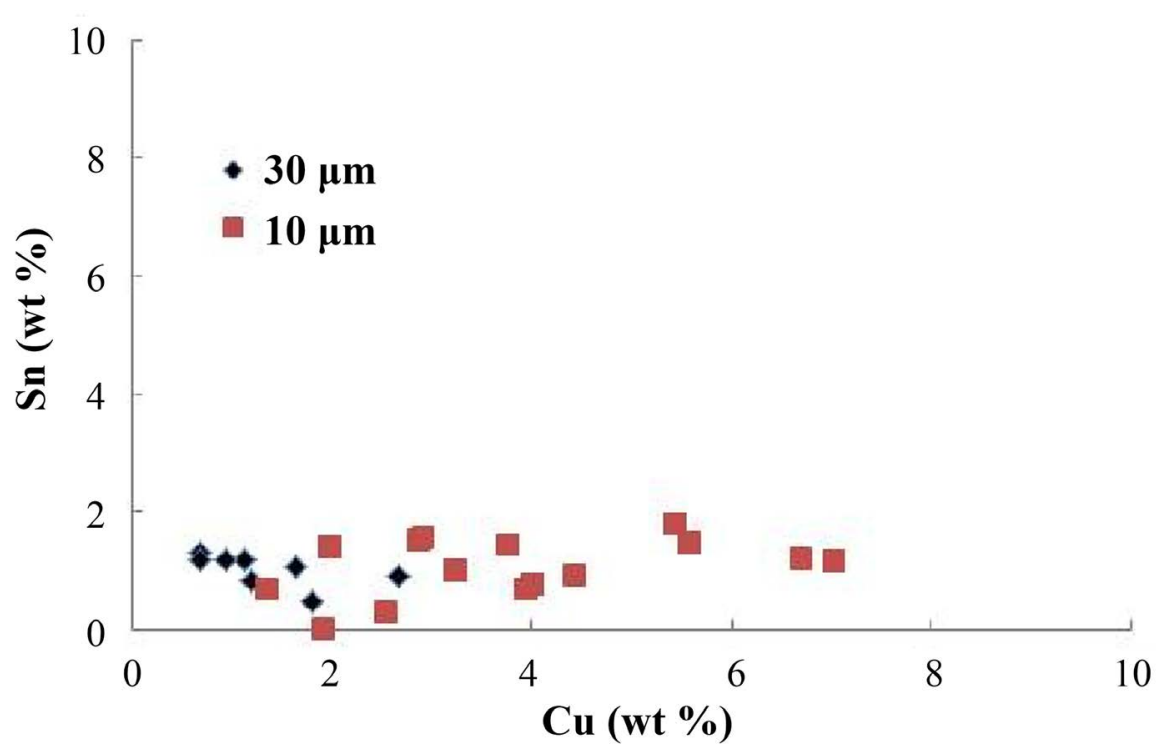

Figure 8. The relationship between the $\mathrm{Cu}$ and $\mathrm{Sn}$ concentrations for the $\mathrm{Ca}-\mathrm{Pb}$ compounds.

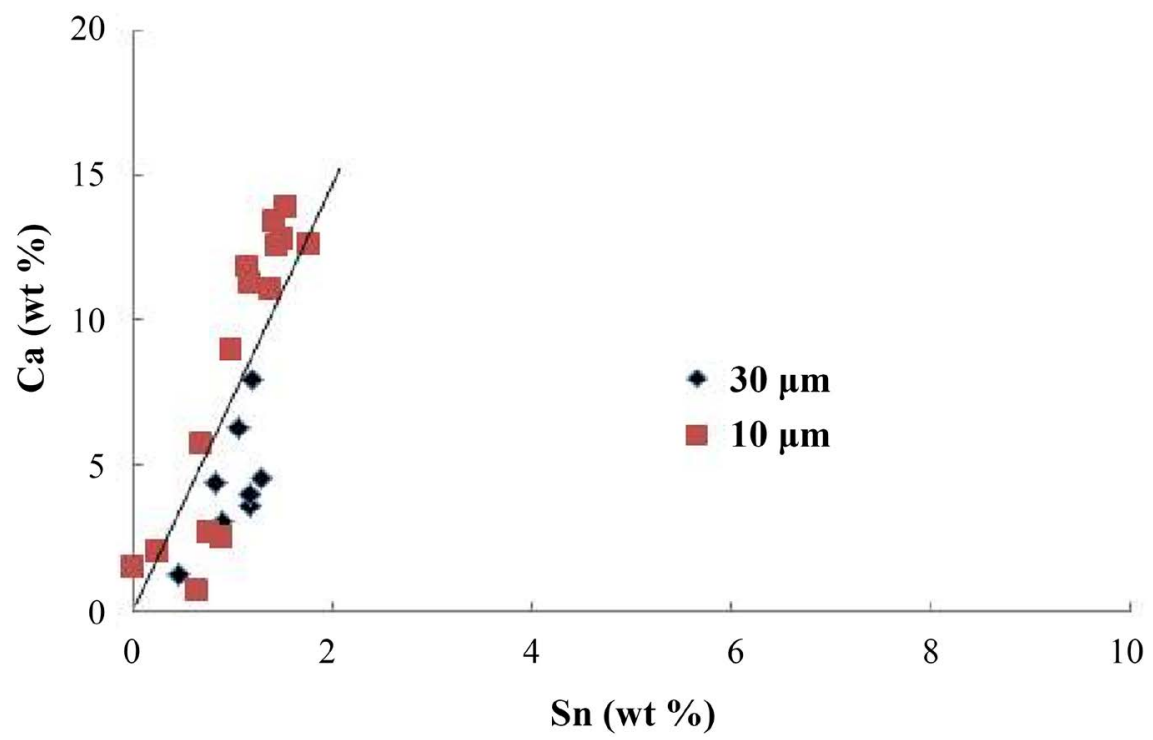

Figure 9. The relationship between the $\mathrm{Ca}$ and $\mathrm{Sn}$ concentrations for the $\mathrm{Ca}-\mathrm{Pb}$ compounds.

Figure 10 shows the relationship between the $\mathrm{Ca}$ and $\mathrm{O}$ concentrations. There was no clear relationship between these. The authors et al. have reported that $\mathrm{XRD}$ analysis of the slag skimmed from the surface of the molten brass after the addition of $2 \mathrm{wt} \% \mathrm{Ca}$ revealed that $\mathrm{Ca}_{2} \mathrm{~Pb}$ was formed in the molten brass, and then $\mathrm{Ca}_{2} \mathrm{~Pb}$ was oxidized during air cooling after skimming, resulting in the formation of $\mathrm{Ca}_{2} \mathrm{PbO}_{4}$ [9]. According to the phase diagram for a Ca-Pb-O system [19] at $827^{\circ} \mathrm{C}$, when the oxygen chemical potential $\Delta \mu_{\mathrm{O} 2}$ is lower than -220 $\mathrm{kJ} / \mathrm{mol}, \Delta \mu_{\mathrm{O} 2}$ is from -50 to $-220 \mathrm{~kJ} / \mathrm{mol}$ and $\Delta \mu_{\mathrm{O} 2}$ from 0 to $-50 \mathrm{~kJ} / \mathrm{mol}$, equilibrium phases are $\mathrm{CaO}+\mathrm{Pb}, \mathrm{CaO}+\mathrm{PbO}$ and $\mathrm{CaO}+\mathrm{Ca}_{2} \mathrm{PbO}_{4}$ (a low $\mathrm{Pb}$ mole 


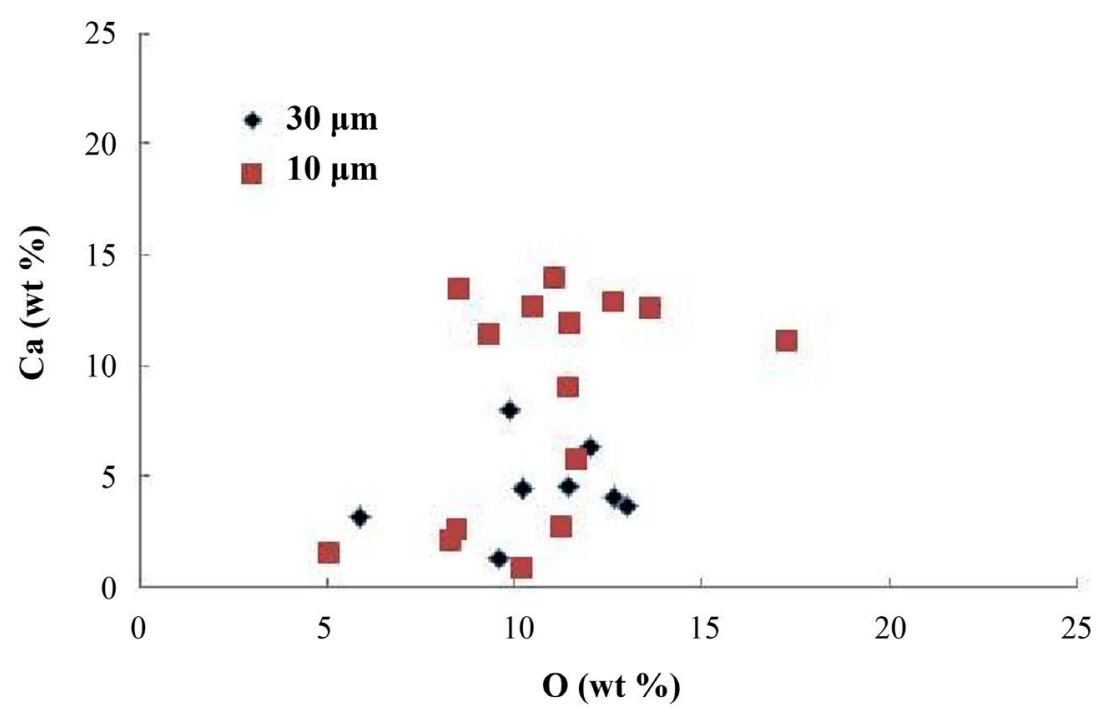

Figure 10. The relationship between the $\mathrm{Ca}$ and $\mathrm{O}$ concentrations for the $\mathrm{Ca}-\mathrm{Pb}$ compounds.

fraction) or $\mathrm{Ca}_{2} \mathrm{PbO}_{4}+\mathrm{PbO}$ (a high $\mathrm{Pb}$ mole fraction), respectively. Therefore, it is thought that the equilibrium phase in the molten brass is $\mathrm{CaO}+\mathrm{Pb}$ and that $\mathrm{Ca}_{2} \mathrm{PbO}_{4}$ is not formed in the molten brass. The existence of $\mathrm{CaO}$ in the slag has been confirmed by XRD [9]. If an oxide based on a Ca-Pb-O system is formed by the addition of $\mathrm{Ca}$, instead of a $\mathrm{Ca}-\mathrm{Pb}$ compound, a proportional relationship (a stoichiometric relationship) should be established between the $\mathrm{Ca}$ and $\mathrm{O}$ concentrations. However, no such relationship was found as shown in Figure 10. Furthermore, no $\mathrm{Ca}-\mathrm{Pb}-\mathrm{O}$ system oxide peak was detected as shown in Figure 5. These findings suggest that the presence of $\mathrm{O}$ in the $\mathrm{Ca}-\mathrm{Pb}$ compound is due to fine grains of $\mathrm{CaO}$ which contaminated together with the molten brass, filling the space between aggregated $\mathrm{Ca}-\mathrm{Pb}$ compound grains.

\subsection{Mechanism for the Formation of Ca-Pb Compounds}

A schematic illustration of the central cross section of a $\mathrm{Ca}-\mathrm{Pb}$ compound based on the XRD and SEM-EDS results is shown in Figure 11. Some of the added Ca is consumed as $\mathrm{CaO}$, but the amount is very small. The concentration of $\mathrm{Ca}$ in the molten brass gradually increases with the injection of more Ca. According to the thermochemical simulation by Hilgendorf et al., $\mathrm{CaPb}$ is the chief compound formed by the addition of $0.7 \mathrm{wt} \% \mathrm{Ca}$ [5]. Therefore, when the grain size of liquid phase $\mathrm{Pb}$ is sub- $\mu \mathrm{m}$, at first, $\mathrm{CaPb}$ may be formed. It is thought that as the concentration of $\mathrm{Ca}$ in the molten brass gradually increases, the $\mathrm{CaPb}$ transforms into $\mathrm{Ca}_{5} \mathrm{~Pb}_{3}$ at a $\mathrm{Ca}$ concentration of $1.5 \mathrm{wt} \%$ and then transforms into $\mathrm{Ca}_{2} \mathrm{~Pb}$ at a $\mathrm{Ca}$ concentration of $1.8 \mathrm{wt} \%$. Then, finally, a single phase compound consisting entirely of $\mathrm{Ca}_{2} \mathrm{~Pb}$ is formed as illustrated in Figure 11(a). The diffusion of atoms in intermetallic compounds takes place via vacancies [20]. Since the atomic radius of $\mathrm{Ca}(0.174 \mathrm{~nm})$ is greater than that of both $\mathrm{Pb}(0.147 \mathrm{~nm})$ and $\mathrm{Sn}(0.140 \mathrm{~nm})$, the diffusion rate of Ca toward the center of a Ca-Pb compound is 

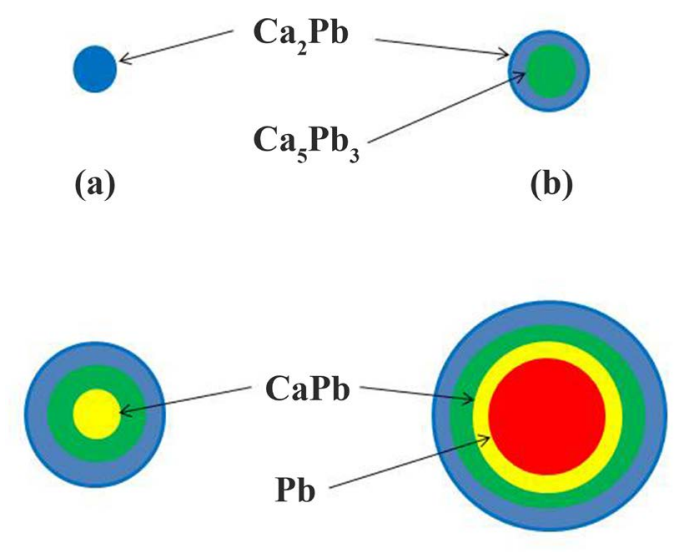

(c)

(d)

Figure 11. Schematic illustration of the central cross section of a $\mathrm{Ca}-\mathrm{Pb}$ compound.

likely to be low. Also, since diffusion depth is proportional to the half power of time, the diffusion depth is also likely small as the holding time is short. Therefore, when the size of the $\mathrm{Pb}$ is slightly larger, a dual phase compound containing $\mathrm{Ca}_{5} \mathrm{~Pb}_{3}$ in the center may be formed as shown in Figure 11(b). Furthermore, as the grain size of the $\mathrm{Pb}$ increases still more, the $\mathrm{CaPb}$ will remain in the center, resulting in the formation of a tri-phase compound as shown in Figure 11(c). When the grain size of the $\mathrm{Pb}$ is several $\mu \mathrm{m}$, unreacted $\mathrm{Pb}$ will remain in the center, and specific compound is thought to be formed, as shown in Figure 11(d). Thus, since the composition of the $\mathrm{Ca}-\mathrm{Pb}$ compound depends on the diffusion of $\mathrm{Ca}$ atoms moving inward through the $\mathrm{Ca}-\mathrm{Pb}$ compound formed on the surface of the $\mathrm{Pb}$, the specific composition will vary, depending largely on the grain size of the $\mathrm{Pb}$. Generally, the smaller the particle size, the larger its surface energy becomes, so it tends to aggregate more actively. That is why the aggregation of the small $\mathrm{Ca}-\mathrm{Pb}$ compounds shown in Figures 11(a)-(c) occurs. Even a relatively large $\mathrm{Ca}-\mathrm{Pb}$ compound, as shown in Figure 11(d), it is considered that aggregation occurs via small $\mathrm{Ca}-\mathrm{Pb}$ compounds such as Figures 11(a)-(c). The findings that the $\mathrm{Pb}$ concentration in large aggregated $\mathrm{Ca}-\mathrm{Pb}$ compounds with grain sizes of 10 and $30 \mu \mathrm{m}$ was larger than the chemical stoichiometric values of $\mathrm{a} \mathrm{Ca}-\mathrm{Pb}$ compound (Figure 7) and that $\mathrm{Pb}$ was identified in $\mathrm{XRD}$ profile (Figure 5) are considered to be due to the composition of the $\mathrm{Ca}-\mathrm{Pb}$ compound, as shown in Figure 10. Sn forms a solid solution in the $\mathrm{Ca}-\mathrm{Pb}$ compound, as mentioned above. It is thought that the possibilityof forming the $\mathrm{Ca}-\mathrm{Pb}$ compound (Figure $11(\mathrm{~d})$ ) containing unreacted $\mathrm{Pb}$ in the center increases because the diffusion rate of $\mathrm{Ca}$ in the $\mathrm{Ca}-\mathrm{Pb}$ compound decreases due to the $\mathrm{Sn}$ solid solution.

\subsection{The Kinetics of Ca- $\mathrm{Pb}$ Compounds in Molten Brass}

Assuming the $\mathrm{Ca}-\mathrm{Pb}$ compound to be a sphere, the resultant force (floating force) of the weight and buoyancy of a $\mathrm{Ca}-\mathrm{Pb}$ compound is expressed by the following equation, when the upward direction is positive [21], 


$$
\begin{gathered}
F=\left(\rho_{f}-\rho_{s}\right) \quad v g \\
v=4 \pi(D / 2)^{3} / 3
\end{gathered}
$$

where $F$ is the floating force, $\rho_{f}$ is the density of the molten brass $\left(7.22 \mathrm{~g} / \mathrm{cm}^{3}\right.$ at $930^{\circ} \mathrm{C}$ ) [22], $\rho_{s}$ is the density of the $\mathrm{Ca}-\mathrm{Pb}$ compound, $v$ and $D$ are the volume and diameter of the $\mathrm{Ca}-\mathrm{Pb}$ compound, and $g$ is gravitational acceleration. $F$ becomes positive when the value of $\rho_{s}$ is less than that of $\rho_{f}$ resulting in the rise of the $\mathrm{Ca}-\mathrm{Pb}$ compound. The densities of solid phase $\mathrm{Ca}_{2} \mathrm{~Pb}$, solid phase $\mathrm{Ca}_{5} \mathrm{~Pb}_{3}$, solid phase $\mathrm{CaPb}$, liquid phase $\mathrm{Pb}\left(680^{\circ} \mathrm{C}\right)$ and solid phase $\mathrm{NaF}$ are 4.8 [23], 5.1 [23], 6.8 [23], 10.2 [24] and $2.79 \mathrm{~g} / \mathrm{cm}^{3}$, respectively. Table 1 shows the type, composition, value of $\left(\rho_{f}-\rho_{s}\right)$ and value of $F$ for various $\mathrm{Ca}-\mathrm{Pb}$ compounds. In addition to the four types $(\mathrm{a}-\mathrm{d})$ shown in Figure 10 , a $\mathrm{Ca}-\mathrm{Pb}$ compound produced by mixed aggregation is indicated by type $\mathrm{A}$. The values for $\mathrm{Ca}-\mathrm{Pb}$ compound produced by mixed aggregation of the three types ( $a, b$ and $c$ ) are thought to be in the range of the values for type a to the values for type $c$, depending on the composition ratio. For a composite $\mathrm{Ca}-\mathrm{Pb}$ compound formed by the subsequent $\mathrm{NaF}$ addition, the symbol of $F$ was added after the type symbol. The number before the material symbol for the composition of $\mathrm{Ca}-\mathrm{Pb}$ compounds indicates the volume fraction (vol\%). Regarding the composition of type $\mathrm{A}, \mathrm{Ca}_{2} \mathrm{~Pb}$ was used as the representative of a multiphase $\mathrm{Ca}-\mathrm{Pb}$ compound. The molten brass, $\mathrm{CaO}$ and $\mathrm{Sn}$ existing in the $\mathrm{Ca}-\mathrm{Pb}$ compound were ignored.

When the Reynolds number of a fluid is less than 2, the rising terminal velocity of a sphere and the time until the $\mathrm{Ca}-\mathrm{Pb}$ compound reach the surface of the molten brass from the bottom of the crucible are expressed by the following equations [21],

\begin{tabular}{|c|c|c|c|c|c|c|c|c|}
\hline \multirow[t]{2}{*}{$\begin{array}{l}\text { Type Ca-Pb } \\
\text { compound }\end{array}$} & \multirow[t]{2}{*}{ Composition } & \multirow{2}{*}{$\begin{array}{l}\left(\rho_{f}-\rho_{s}\right) \\
\left(\mathrm{g} / \mathrm{cm}^{3}\right)\end{array}$} & \multicolumn{6}{|c|}{$F\left(\mathrm{~g} \mathrm{~cm} / \mathrm{s}^{2}\right)$} \\
\hline & & & $D: 1 \mu \mathrm{m}$ & $D: 2 \mu \mathrm{m}$ & $D: 3 \mu \mathrm{m}$ & $D: 5 \mu \mathrm{m}$ & $D: 10 \mu \mathrm{m}$ & $D: 30 \mu \mathrm{m}$ \\
\hline a & $100 \mathrm{Ca}_{2} \mathrm{~Pb}$ & 2.42 & $1.24 \times 10^{-9}$ & $9.94 \times 10^{-9}$ & $3.34 \times 10^{-8}$ & $1.55 \times 10^{-7}$ & $1.24 \times 10^{-6}$ & $3.34 \times 10^{-5}$ \\
\hline $\mathrm{b}$ & $50 \mathrm{Ca}_{2} \mathrm{~Pb}-50 \mathrm{Ca}_{5} \mathrm{~Pb}_{3}$ & 2.27 & & $9.32 \times 10^{-9}$ & $3.14 \times 10^{-8}$ & $1.45 \times 10^{-7}$ & $1.17 \times 10^{-6}$ & $3.14 \times 10^{-5}$ \\
\hline c & $40 \mathrm{Ca}_{2} \mathrm{~Pb}-40 \mathrm{Ca}_{5} \mathrm{~Pb}_{3}-20 \mathrm{CaPb}$ & 1.9 & & & $2.63 \times 10^{-8}$ & $1.22 \times 10^{-7}$ & $9.76 \times 10^{-7}$ & $2.63 \times 10^{-5}$ \\
\hline $\mathrm{d} 1$ & $25 \mathrm{Ca}_{2} \mathrm{~Pb}-25 \mathrm{Ca}_{5} \mathrm{~Pb}_{3}-25 \mathrm{CaPb}-25 \mathrm{~Pb}$ & 0.5 & & & & $3.20 \times 10^{-8}$ & $2.57 \times 10^{-7}$ & $6.91 \times 10^{-6}$ \\
\hline $\mathrm{d} 2$ & $20 \mathrm{Ca}_{2} \mathrm{~Pb}-20 \mathrm{Ca}_{5} \mathrm{~Pb}_{3}-20 \mathrm{CaPb}-40 \mathrm{~Pb}$ & -0.2 & & & & & & \\
\hline $\mathrm{dF}$ & $\begin{array}{c}12 \mathrm{Ca}_{2} \mathrm{~Pb}-12 \mathrm{Ca}_{5} \mathrm{~Pb}_{3}-12 \mathrm{CaPb}-24 \mathrm{~Pb}-40 \mathrm{NaF} \\
\left(60 \mathrm{~d}_{2}-40 \mathrm{NaF}\right)\end{array}$ & 1.65 & & & & & $1.08 \times 10^{-6}$ & $2.92 \times 10^{-5}$ \\
\hline A1 & $70 \mathrm{Ca}_{2} \mathrm{~Pb}-30 \mathrm{~Pb}$ & 0.8 & & & & & $4.11 \times 10^{-7}$ & $1.10 \times 10^{-5}$ \\
\hline A2 & $60 \mathrm{Ca}_{2} \mathrm{~Pb}-40 \mathrm{~Pb}$ & 0.26 & & & & & $1.34 \times 10^{-7}$ & $3.59 \times 10^{-6}$ \\
\hline A3 & $50 \mathrm{Ca}_{2} \mathrm{~Pb}-50 \mathrm{~Pb}$ & -0.28 & & & & & & \\
\hline AF1 & $30 \mathrm{Ca}_{2} \mathrm{~Pb}-30 \mathrm{~Pb}-40 \mathrm{NaF}(60 \mathrm{~A} 3-40 \mathrm{NaF})$ & 1.6 & & & & & $8.22 \times 10^{-7}$ & $2.21 \times 10^{-5}$ \\
\hline AF2 & $25 \mathrm{Ca}_{2} \mathrm{~Pb}-25 \mathrm{~Pb}-50 \mathrm{NaF}(50 \mathrm{~A} 3-50 \mathrm{NaF})$ & 2.07 & & & & & $1.06 \times 10^{-6}$ & $2.86 \times 10^{-5}$ \\
\hline
\end{tabular}

Table 1. The type, composition, value of $\left(\rho_{f}-\rho_{s}\right)$ and value of $F$ for various $\mathrm{Ca}-\mathrm{Pb}$ compounds. 


$$
\begin{gathered}
V_{t}=g \cdot D^{2}\left(\rho_{f}-\rho_{\mathrm{s}}\right) / 18 \mu \\
T_{t}=H / V_{t}
\end{gathered}
$$

where $V_{t}$ is the rising terminal velocity of a sphere and $\mu$ is a viscosity of the molten brass $\left(3.49 \times 10^{-3} \mathrm{~g} /(\mathrm{cm} \cdot \mathrm{s})\right.$ at $\left.930^{\circ} \mathrm{C}\right)[22], T_{t}$ is the time until the $\mathrm{Ca}-\mathrm{Pb}$ compound reaches the surface of the molten brass from the bottom of the crucible, and $H$ is the height of the molten brass $(18 \mathrm{~cm})$. Differences in surface tension were ignored. Table 2 shows the values of $V_{t}$ and $T_{t}$. When the $\mathrm{Ca}-\mathrm{Pb}$ compound is formed and then begins to rise in the molten brass, the rising terminal velocity (constant velocity) is not immediately reached; it takes time. Therefore, the time until the compound actually reaches the surface of the molten brass is longer than the value of $T_{t}$ in Table 2. Since electromagnetic molten brass flow in which the molten brass continuously flows upward near the center of the induction furnace and downward near the furnace wall exists, the value of $V_{t}$ near the center of the furnace is greater than that in Table 2, while the opposite is the case near the furnace wall.

Since the value of $\left(\rho_{f}-\rho_{s}\right)$ is positive when the whole grain consists of a $\mathrm{Ca}-\mathrm{Pb}$ compound (of type $\mathrm{a}, \mathrm{b}$ or $\mathrm{c}$ ), these compounds rise in the molten brass. However, when the grain size of the $\mathrm{Ca}-\mathrm{Pb}$ compound is small, it takes a longer time to reach the surface of the molten brass because of the small $V_{t}$ (Table 2). Therefore, it is thought that these compounds tend to aggregate with each other into a large compound for the purpose of reducing a large surface energy. It is believed that the aggregated $\mathrm{Ca}-\mathrm{Pb}$ compounds that have a $D$ larger than $10 \mu \mathrm{m}$ reach the surface of the molten brass in a short time (Table 2) because of their large $V_{t}$ and then they continue to float on the surface of the molten brass because of their large $F$ (greater than $10^{-6} \mathrm{~g} \cdot \mathrm{cm} / \mathrm{s}^{2}$ ). This is very convenient for the removal of $\mathrm{Pb}$ from the molten brass. The reason that the compounds larger than $10 \mu \mathrm{m}$ and consisting of $\mathrm{Ca}-\mathrm{Pb}$ compound alone were absent, as shown in Figure 3, Figure 4 and Figure 7, is due to this phenomenon.

In the case of $\mathrm{Ca}-\mathrm{Pb}$ compounds that contain unreacted $\mathrm{Pb}$ in the center, the value of $\left(\rho_{f}-\rho_{s}\right)$ of a $\mathrm{Ca}-\mathrm{Pb}$ compound containing $25 \mathrm{vol} \% \mathrm{~Pb}$ (type $\left.\mathrm{d} 1\right)$ was positive, but when one contained $40 \mathrm{vol} \% \mathrm{~Pb}$ (type $\mathrm{d} 2$ ) the value was negative. This is due to the large amounts of heavy $\mathrm{Pb}$. It is thought that even when $D$ is $10 \mu \mathrm{m}$, a Ca- $\mathrm{Pb}$ compound containing $25 \mathrm{vol} \% \mathrm{~Pb}$ does not float on the surface of the molten brass, due to its small $F$ value (less than $10^{-6} \mathrm{~g} \cdot \mathrm{cm} / \mathrm{s}^{2}$ ). It returns back into the molten brass, due to the electromagnetic molten brass flow. The reason that only $\mathrm{Ca}-\mathrm{Pb}$ compound containing unreacted $\mathrm{Pb}$ and also with a $D$ less than $10 \mu \mathrm{m}$ was observed, as shown in Figure 3, Figure 4 and Figure 7, is due to this phenomenon. On the other hand, it is believed that when $D$ is $30 \mu \mathrm{m}$, types $\mathrm{d} 1$ and $\mathrm{d} 2$ float on the surface of the molten brass, due to their large $F$ values (greater than $10^{-6} \mathrm{~g} \cdot \mathrm{cm} / \mathrm{s}^{2}$ ). Thus, it is believed that $\mathrm{Ca}-\mathrm{Pb}$ compounds with $F$ values greater than $10^{-6} \mathrm{~g} \cdot \mathrm{cm} / \mathrm{s}^{2}$ continue to float on the surface of the molten brass, while $\mathrm{Ca}-\mathrm{Pb}$ compounds with $F$ values less than $10^{-6} \mathrm{~g} \cdot \mathrm{cm} / \mathrm{s}^{2}$ return back into the molten brass due to the electromagnetic molten brass flow. 
Table 2. The values of $V_{t}$ and $T_{t}$ for various $\mathrm{Ca}-\mathrm{Pb}$ compounds.

\begin{tabular}{|c|c|c|c|c|c|c|c|}
\hline \multirow[t]{2}{*}{ Type } & \multirow[t]{2}{*}{ Composition } & \multicolumn{6}{|c|}{$V_{t}(\mathrm{~cm} / \mathrm{s})\left(T_{t}(\mathrm{~s})\right)$} \\
\hline & & $D: 1 \mu \mathrm{m}$ & $D: 2 \mu \mathrm{m}$ & $D: 3 \mu \mathrm{m}$ & $D: 5 \mu \mathrm{m}$ & $D: 10 \mu \mathrm{m}$ & $D: 30 \mu \mathrm{m}$ \\
\hline a & $100 \mathrm{Ca}_{2} \mathrm{~Pb}$ & $\begin{array}{c}3.70 \times 10^{-2} \\
\left(4.86 \times 10^{2}\right)\end{array}$ & $\begin{array}{l}1.48 \times 10^{-1} \\
\left(1.22 \times 10^{2}\right)\end{array}$ & $\begin{array}{l}3.33 \times 10^{-1} \\
(5.41 \times 10)\end{array}$ & $\begin{array}{l}9.25 \times 10^{-1} \\
(1.95 \times 10)\end{array}$ & $3.70(4.86)$ & $\begin{array}{c}3.33 \times 10 \\
\left(5.41 \times 10^{-1}\right)\end{array}$ \\
\hline $\mathrm{b}$ & $50 \mathrm{Ca}_{2} \mathrm{~Pb}-50 \mathrm{Ca}_{5} \mathrm{~Pb}_{3}$ & & $\begin{array}{l}1.39 \times 10^{-1} \\
\left(1.29 \times 10^{2}\right)\end{array}$ & $\begin{array}{l}3.12 \times 10^{-1} \\
(5.77 \times 10)\end{array}$ & $\begin{array}{l}8.68 \times 10^{-1} \\
(2.07 \times 10)\end{array}$ & $3.47(5.19)$ & $\begin{array}{c}3.12 \times 10 \\
\left(5.76 \times 10^{-1}\right)\end{array}$ \\
\hline c & $40 \mathrm{Ca}_{2} \mathrm{~Pb}-40 \mathrm{Ca}_{5} \mathrm{~Pb}_{3}-20 \mathrm{CaPb}$ & & & $\begin{array}{l}2.61 \times 10^{-1} \\
(6.90 \times 10)\end{array}$ & $\begin{array}{l}7.26 \times 10^{-1} \\
(2.48 \times 10)\end{array}$ & $2.91(6.19)$ & $\begin{array}{c}2.61 \times 10 \\
\left(6.90 \times 10^{-1}\right)\end{array}$ \\
\hline $\mathrm{d} 1$ & $25 \mathrm{Ca}_{2} \mathrm{~Pb}-25 \mathrm{Ca}_{5} \mathrm{~Pb}_{3}-25 \mathrm{CaPb}-25 \mathrm{~Pb}$ & & & & $\begin{array}{l}1.91 \times 10^{-1} \\
(9.42 \times 10)\end{array}$ & $\begin{array}{l}7.65 \times 10^{-1} \\
(2.35 \times 10)\end{array}$ & $6.88(2.62)$ \\
\hline $\mathrm{dF}$ & $\begin{array}{c}12 \mathrm{Ca}_{2} \mathrm{~Pb}-12 \mathrm{Ca}_{5} \mathrm{~Pb}_{3}-12 \mathrm{CaPb}-224 \mathrm{~Pb}- \\
40 \mathrm{NaF}(60 \mathrm{~d} 2-40 \mathrm{NaF})\end{array}$ & & & & & $2.52(7.14)$ & $\begin{array}{c}2.27 \times 10 \\
\left(7.93 \times 10^{-1}\right)\end{array}$ \\
\hline $\mathrm{A} 1$ & $70 \mathrm{Ca}_{2} \mathrm{~Pb}-30 \mathrm{~Pb}$ & & & & $\begin{array}{l}3.06 \times 10^{-1} \\
(8.74 \times 10)\end{array}$ & $1.22(1.48 \times 10)$ & $\begin{array}{l}1.10 \times 10 \\
(1.64)\end{array}$ \\
\hline $\mathrm{A} 2$ & $60 \mathrm{Ca}_{2} \mathrm{~Pb}-40 \mathrm{~Pb}$ & & & & & $\begin{array}{l}3.98 \times 10^{-1} \\
(4.52 \times 10)\end{array}$ & $3.58(5.03)$ \\
\hline AF1 & $30 \mathrm{Ca}_{2} \mathrm{~Pb}-30 \mathrm{~Pb}-40 \mathrm{NaF}(60 \mathrm{~A} 3-40 \mathrm{NaF})$ & & & & & $2.45(7.35)$ & $\begin{array}{c}2.20 \times 10 \\
\left(8.18 \times 10^{-1}\right)\end{array}$ \\
\hline AF2 & $25 \mathrm{Ca}_{2} \mathrm{~Pb}-25 \mathrm{~Pb}-50 \mathrm{NaF}(50 \mathrm{~A} 3-50 \mathrm{NaF})$ & & & & & $3.17(5.68)$ & $\begin{array}{c}2.85 \times 10 \\
\left(6.32 \times 10^{-1}\right)\end{array}$ \\
\hline
\end{tabular}

${ }^{\star}$ The compositions of types $\mathrm{d} 2$ and $\mathrm{A} 3$ are the same as Table 1.

In the case of aggregated $\mathrm{Ca}-\mathrm{Pb}$ compounds that are mixed with types $\mathrm{a}, \mathrm{b}, \mathrm{c}$ and $\mathrm{d}$, the value $\left(\rho_{f}-\rho_{s}\right)$ of 50 vol\% $\mathrm{Pb}$ (type A3) was negative. Even in the case of 30 vol\% $\mathrm{Pb}$ (type $\mathrm{A} 1$ ) and 40 vol\% $\mathrm{Pb}$ (type A2), the values of $F$ were low (less than $10^{-6} \mathrm{~g} \cdot \mathrm{cm} / \mathrm{s}^{2}$ ) when $D$ was $10 \mu \mathrm{m}$. Therefore, these compounds thought to return back into the molten brass without floating. However, it is thought that when $D$ is $30 \mu \mathrm{m}$, the $\mathrm{Ca}-\mathrm{Pb}$ compounds continue to float on the surface of the molten brass due to their large $F$ values (greater than $10^{-6} \mathrm{~g} \cdot \mathrm{cm} / \mathrm{s}^{2}$ ).

The values $\left(\rho_{f}-\rho_{s}\right)$ of types $\mathrm{dF}$ and $\mathrm{A} 3$ containing a large amount of $\mathrm{Pb}$ were negative. However, the values $\left(\rho_{f}-\rho_{s}\right)$ of composite $\mathrm{Ca}-\mathrm{Pb}$ compounds with the light $\mathrm{NaF}$ (types dF, AF1 andAF2) were positive. Even when $D$ was $10 \mu \mathrm{m}$, the value of $F$ for type AF1 was close to $10^{-6} \mathrm{~g} \cdot \mathrm{cm} / \mathrm{s}^{2}$. When $D$ is $30 \mu \mathrm{m}$, these compounds continue to float on the surface of the molten brass because of their large $F$ values (larger than $10^{-6} \mathrm{~g} \cdot \mathrm{cm} / \mathrm{s}^{2}$ ). In the case of $\mathrm{dF}$ and $\mathrm{AF} 2$, it is considered that even when $D$ is $10 \mu \mathrm{m}$, these compounds float on the surface of the molten brass because of their large $F$ values (larger than $10^{-6} \mathrm{~g} \cdot \mathrm{cm} / \mathrm{s}^{2}$ ). The $\mathrm{Pb}$ removal rate can be improved by subsequent $\mathrm{NaF}$ addition [7] [9]. This is due to the formation of light composite $\mathrm{Ca}-\mathrm{Pb}$ compounds containing $\mathrm{NaF}$, as mentioned above. Table 2 shows that huge aggregated compounds with $D$ of $30 \mu \mathrm{m}$ reach the surface of the molten brass within several seconds, regardless of the composition of the $\mathrm{Ca}-\mathrm{Pb}$ compounds. They continue to float on the surface of the molten brass because of $F$ values greater than $10^{-6} \mathrm{~g} \cdot \mathrm{cm} / \mathrm{s}^{2}$, making skimming off 
them possible. Thus, the effect of grain size on the kinetics of $\mathrm{Ca}-\mathrm{Pb}$ compound is larger than that of the composition of the $\mathrm{Ca}-\mathrm{Pb}$ compound.

\section{Conclusion}

It was revealed that the composition of $\mathrm{Ca}-\mathrm{Pb}$ compound depends on the grain size of liquid phase $\mathrm{Pb}$ and the diffusion of $\mathrm{Ca}$ migrating inward through the $\mathrm{Ca}-\mathrm{Pb}$ compound that forms on the surface of the $\mathrm{Pb}$. In the case of a fine $\mathrm{Pb}$ grain, the whole grain consists of a $\mathrm{Ca}-\mathrm{Pb}$ compound, whereas in the case of a large $\mathrm{Pb}$ grain (several $\mu \mathrm{m}$ in size) a $\mathrm{Ca}-\mathrm{Pb}$ compound containing unreacted $\mathrm{Pb}$ in the center is formed. The $\mathrm{Ca}-\mathrm{Pb}$ compounds aggregate with each other into a larger compound grain. It was revealed that whether the $\mathrm{Ca}-\mathrm{Pb}$ compound floats on the surface of the molten brass depend on the magnitude of a floating force. Because a $\mathrm{Ca}-\mathrm{Pb}$ compound whose floating force is less than $10^{-6} \mathrm{~g} \cdot \mathrm{cm} / \mathrm{s}^{2}$ does not have a sufficient floating force, once it rises near the surface of the molten brass, it returns back into the molten brass, due to the electromagnetic molten brass flow. Therefore, it is difficult to simply skim off these $\mathrm{Ca}-\mathrm{Pb}$ compounds. A $\mathrm{Ca}-\mathrm{Pb}$ compound with a floating force greater than $10^{-6} \mathrm{~g} \cdot \mathrm{cm} / \mathrm{s}^{2}$ has a large rising terminal velocity and therefore reaches the surface of the molten brass in a short time. Moreover, it keeps on floating because of its large floating force. In particular, $\mathrm{Ca}-\mathrm{Pb}$ compounds with a large grain size $(30 \mu \mathrm{m})$ have a greater floating force than $10^{-6} \mathrm{~g} \cdot \mathrm{cm} / \mathrm{s}^{2}$ and a large rising terminal velocity, regardless of their compositions. Since they continue to float on the surface of the molten brass, it is easy to remove these compounds by skimming. Thus, it was revealed that the effects of the grain size of the $\mathrm{Ca}-\mathrm{Pb}$ compound on the floating force and the rising terminal velocity are greater than that of the composition of the $\mathrm{Ca}-\mathrm{Pb}$ compound. It is due to such kinetics that a $\mathrm{Pb}$ removal rate of about $20 \%$ was achieved by the addition of $\mathrm{Ca}$ alone. The reason that a $\mathrm{Pb}$ removal rate close to the theoretical value can be achieved by further addition of $\mathrm{NaF}$ is that a light composite $\mathrm{Ca}-\mathrm{Pb}$ compound containing $\mathrm{NaF}$ is formed and that it tends to float on the surface of the molten brass, due to its large floating force and large rising terminal velocity. For a fluorine-free $\mathrm{Pb}$ removal method, it will be important to develop a new technology to increase the floating force and the rising terminal velocity of not only aggregated $\mathrm{Ca}-\mathrm{Pb}$ compounds consisting of $\mathrm{Ca}-\mathrm{Pb}$ compounds alone but also of aggregated $\mathrm{Ca}-\mathrm{Pb}$ compounds containing unreacted $\mathrm{Pb}$ in the center.

\section{Acknowledgements}

This work was supported by the Ministry of Economy, Trade and Industry of Japan under a Grant [The energy-saving recycling process support project].

\section{Conflicts of Interest}

The authors declare no conflicts of interest regarding the publication of this paper. 


\section{References}

[1] Japan Foundry Engineering Society (2002) Chuzo-Kogaku Binran. Maruzen, Tokyo, 473-474. (In Japanese)

[2] European Commission (2015) Commission Regulation (EU) 2015/628 Amending Annex XVII to Regulation (EU) No 1907/2006 of the European Parliament and of the Council on the Reaction, Evaluation, Authorization and Restriction of Chemicals ("REACH") as Regard Lead Its Compounds, European Commission, Brussels.

[3] The Safe Drinking Water Act (2011) An Act to Amend the Safe Drinking Water Act to Reduce Lead in Drinking Water of 20002, Publ. L. No. 111-380, Sec. 2 (d) (1) (B), Washington.

[4] Grohbauer, A. and Wieland-Werke, A.G. (2012) Verfahren zur Abtrennung von Blei aus dem Messing-Recycling-Kreislauf. DE102011012133A1, German Patent and Trade Mark Office, Munich.

[5] Hilgendorf, S., Binz, F., Welter, J.M. and Friedrich, B. (2016) Lead Removal from Brass Scrap by Fluorine-Free Compound Separation. Materials Science and Technology, 32, 1782-1788. https://doi.org/10.1080/02670836.2016.1223574

[6] Yamada, K., Rochman, N.T., Fujimoto, R., Suehiro, S. and Sueyoshi, H. (2001) Removal of Lead from Scrap Brass. Journal of Advanced Science, 13, 273-276. https://doi.org/10.2978/jsas.13.273

[7] Nakano, A., Rochman, N.T. and Sueyoshi, H. (2005) Removal of Lead from Copper Alloy Scrap by Compound-Separation Method. Materials Transactions, 46, 2719-2724. https://doi.org/10.2320/matertrans.46.2719

[8] Nakano, A., Rochman, N.T. and Sueyoshi, H. (2005) LCA of Manufacturing Lead-Free Copper Alloys. Materials Transactions, 46, 2713-2718.

https://doi.org/10.2320/matertrans.46.2713

[9] Sueyoshi, H., Yamada, K., Miyazaki, M., Okada, T., Ashie, N. and Kousaka, Y. (2018) Mechanism of Pb Removal from Brass Scrap by Compound Separation Using $\mathrm{Ca}$ and $\mathrm{NaF}$. International Journal of Nonferrous Metallurg, 7, 1-7. https://doi.org/10.4236/ijnm.2018.71001

[10] Rao, S.S. and Anantharaman, T.R. (1969) Constitution of Brasses below $500^{\circ} \mathrm{C}$. Zeitschrift für Metallkunde, 60, 312-315.

[11] Murakami, Y. (1972) Lattice Softening, Phase Stability and Elastic Anomaly of the $\beta$-Au-Cu-Zn Alloys. Journal of the Physical Society of Japan, 33, 1350-1360. https://doi.org/10.1143/JPSJ.33.1350

[12] Vishan, V. and Narlikar, A.V. (1976) Structure and Superconductivity of Splat Quenched Pb Bi Solid Solution. Materials Research Bulletin, 11, 1257-1264. https://doi.org/10.1016/0025-5408(76)90030-1

[13] Helleis, O., Kandier, H., Leicht, E., Quiring, W. and Wolfel, E.R. (1963) Die Kristallstrukturen der Intermetallischen Phasen $\mathrm{Ca}_{33} \mathrm{Ge}, \mathrm{Ca}_{7} \mathrm{Ge}, \mathrm{Ca}_{3} \mathrm{~Pb}$ und $\mathrm{Ca}_{5} \mathrm{~Pb}_{3}$. Zeitschrift Anorganische und Allgemeine Chemie, 320, 86-100. https://doi.org/10.1002/zaac.19633200113

[14] Messing, A.F., Adams, M.D. and Steunenberg, R.K. (1963) Contribution to the Phase Diagram Calcium-Zinc. Transactions of the ASM, 56, 345-350.

[15] Buschow, K.H.J. (1974) Calcium-Nickel Intermetallic Compounds. Journal of the Less Common Metals, 38, 95-98. https://doi.org/10.1016/0022-5088(74)90208-2

[16] Itkin, V.P. and Alcock, C.B. (1992) The Ca-Pb (Calcium-Lead) System. Journal of Phase Equilibria, 13, 162-169. https://doi.org/10.1007/BF02667480 
[17] Bruzzone, G. and Merio, F. (1976) The Equilibrium Phase Diagram of the Calcium-Lead System and Crystal Structures of the Compounds $\mathrm{CaPb}, \mathrm{EuPb}$ and $\mathrm{YbPb}$. Journal of the Less Common Metals, 48, 103-109. https://doi.org/10.1016/0022-5088(76)90236-8

[18] Palenzona, A., Manfrinetti, P. and Fomasini, M.L. (2000) Phase Diagram of the Ca-Sn System. Journal of Alloys and Compounds, 312, 165-171. https://doi.org/10.1016/S0925-8388(00)01150-6

[19] Jakob, K.T. and Jayadevan, K.P. (1997) Measurement of Gibbs Energy of Formation of $\mathrm{Ca}_{2} \mathrm{PbO}_{4}$ Using a Solid-State Cell with Three Electrodes. Journal of Materials Chemistry, 7, 2407-2413. https://doi.org/10.1039/a705512i

[20] Mehrer, H. (1996) Diffusion in Intermetallics. Mat. Trans., JIM, 37, 1259-1280. https://doi.org/10.2320/matertrans1989.37.1259

[21] Pozrikidis, C. (2017) Fluid Dynamics: Theory, Computation and Numerical Simulation, Third Edition, Springer, Berlin. https://doi.org/10.1007/978-1-4899-7991-9

[22] JMatPro: Simulation Software for Solidification Behaviour and Properties, Database for Copper Alloys. UES Software Co. Ltd., Fujisawa.

[23] Yang, Z., Shi, D., Wen, B., Melnik, R., Yao, S. and Li, T. (2010) First-Principle Studies of $\mathrm{Ca}-X(X=\mathrm{Si}, \mathrm{Ge}, \mathrm{Sn}, \mathrm{Pb})$ Intermetallic Compounds. Journal of Solid State Chemistry, 183, 136-143. https://doi.org/10.1016/j.jssc.2009.11.007

[24] Okajima, K. and Sakao, H. (1988) Anomalous Property of Liquid Pb-Bi Alloys Determined by EMF and Density Measurements. Transactions of the Japan Institute of Metals, 29, 469-476. 